\title{
Video intervention in statistics learning as a strategy to increase mathematics learning outcomes
}

\author{
Tri Yuni Hendrowati ${ }^{1}$, Rahma Faelasofi ${ }^{1}$ \\ ${ }^{1}$ Universitas Muhammadiyah Pringsewu, Indonesia \\ $₫$ rahmafaelasofi@umpri.ac.id*
}

Article Information

Submitted May 21, 2021

Revised June 07, 2021

Accepted June 09, 2021

\section{Keywords}

Learning Video;

Learning Outcomes.

\begin{abstract}
The COVID-19 pandemic requires the learning process to take place online, this has an impact on teachers who are required to creatively innovate unusual learning processes. This research aims to determine the difference in the average learning outcomes of students during online learning between the application of learning videos before and after receiving the learning video intervention treatment. The research instrument used was a test of statistics material. The learning outcomes test data obtained were processed by paired t-test. This research found that there was a difference in the average learning outcomes of students before and after the application of learning videos. The application of learning videos provides better learning outcomes than before using learning videos.
\end{abstract}

\section{INTRODUCTION}

In fact, education is a system consisting of several components including: students, educators, goals, tools, learning processes and interrelated environments (Hartadi et al., 2020) . Learning is one of the activities in the classroom that involves teachers and students assisted by media, tools, methods, and materials, designed to achieve educational goals (Pane \& Dasopang 2017; Syarifudin 2020). The learning comfort zone that had been going on had to change with the emergence of the COVID-19 pandemic. The learning process that takes place must be done online (in the network) (Rachmat \& Krisnadi 2020).

Based on preliminary studies on several related parties, both teachers and principals of SMP Negeri 2 Bandar Lampung, the information was obtained that students' mathematics learning outcomes were still not optimal in this online learning process, especially on the statistics subject. This is because students still have the notion that mathematics lessons are less fun, stiff, and scary. The information is also obtained based on data from daily tests on statistics subject when online learning takes place, the average percentage of student completeness is $70 \%$, this condition has not reached the specified Minimum Completeness Criteria (KKM) which is 76.

Low motivation allegedly caused by learning techniques that changed drastically with the use of ICT so that many teachers have not mastered these learning techniques, then limitations in terms of tools to support online learning for both educators and students, and the duration of online learning is relatively long so that students get bored quickly because they have to stare at the screen for hours. The condition of online learning makes it difficult for teachers to control and maintain the learning atmosphere because it is limited to virtual spaces (Cahyani et al., 2020). The learning atmosphere created during online learning also affects students' learning motivation, if in offline learning the teacher is able to create a conducive classroom atmosphere to maintain students' learning motivation so that learning can be achieved

How to cite

E-ISSN

Published by
Hendrowati, T. Y., \& Faelasofi, R. (2021). Video intervention in statistics learning as a strategy to increase mathematics learning outcomes. Al-Jabar: Jurnal Pendidikan Matematika, 12(1), 229-236. 2540-7562

Mathematics Education Department, UIN Raden Intan Lampung. 
because the classroom atmosphere has a significant influence on learning motivation (Sari \& Deskoni 2018). This condition has an impact on the low learning outcomes of students.

The thing that needs to be done to overcome this problem is the need of the creativity of mathematics teachers to develop the learning, both in terms of methods and media used to improve student learning outcomes in the online learning process. Online learning is a learning that takes place in a network where teachers and students do not meet face to face (Pohan, 2020). Online learning is considered by the government as a solution to ensure the continuity of the learning process from elementary school to university so that it can continue (Arizona et al., 2020). Online learning has an influence on student achievements (Nugraha et al., 2020; Subur \& Rista 2020). In this research, the application used is the Whatsapp application.

The WhatsApp application is able to accommodate the implementation of the learning process well. Several researches have stated that this application is a good solution in the implementation of the online learning process (Agustin 2020; Bhagaskara et al., 2021; Jumiatmoko 2016; Pustikayasa, 2019). This application is an application that is often used by all smartphone users, making the learning process easier to access. The WhatsApp application has features that support it to become a support media in the teaching and learning process and also help to make the teacher's work easier (Iskandar, 2020). The Whatsapp Group feature is part of the Whatsapp application that can easily reach many people quickly (Saragih \& Ansi 2020; Yensy 2020). One of the media that can be easily spread in Whatsapp Group is video.

The learning video can be used as learning media wherever and whenever according to user needs. The learning video is one type of media to achieve learning objectives that prioritize the power of sound, images and moving animations (Khairani et al., 2019; Nuritha \& Tsurayya 2021; Pamungkas et al. 2018). Educators can easily create an explanation display of an interesting material in a learning video. Several relevant researches on the application of learning videos give positive results. (Iwantara et al.,2014) stated that learning videos increase students' motivation and concepts understanding. The application of learning videos can also improve student learning achievement (Busyaeri et al., 2016; Yunita \& Wijayanti, 2017). The difference that researchers provide in this research is the combination of the use of Whatsapp Groups and learning videos during the COVID-19 pandemic on students' mathematics learning outcomes.

\section{METHODS}

This research is a quantitative research with pre-experimental method and one group pretestposttest research design. This research was conducted in the 8th grade of SMP Negeri 2 Bandar Lampung in the even semester of the 2020-2021 school year. The population of this research was class $8_{1}$ to $8_{10}$ with the sampling technique used was cluster random sampling so that 2 groups of class samples were selected, namely class $8_{1}$ as the experimental class and $8_{2}$ as the control class. The research instrument used in this research was a test of student learning outcomes on the statistics subject, which consisted of 5 questions. Data analysis in this research used paired t-test, provided that the data came from a normally distributed and homogeneous population. Here is a flow chart of this research: 


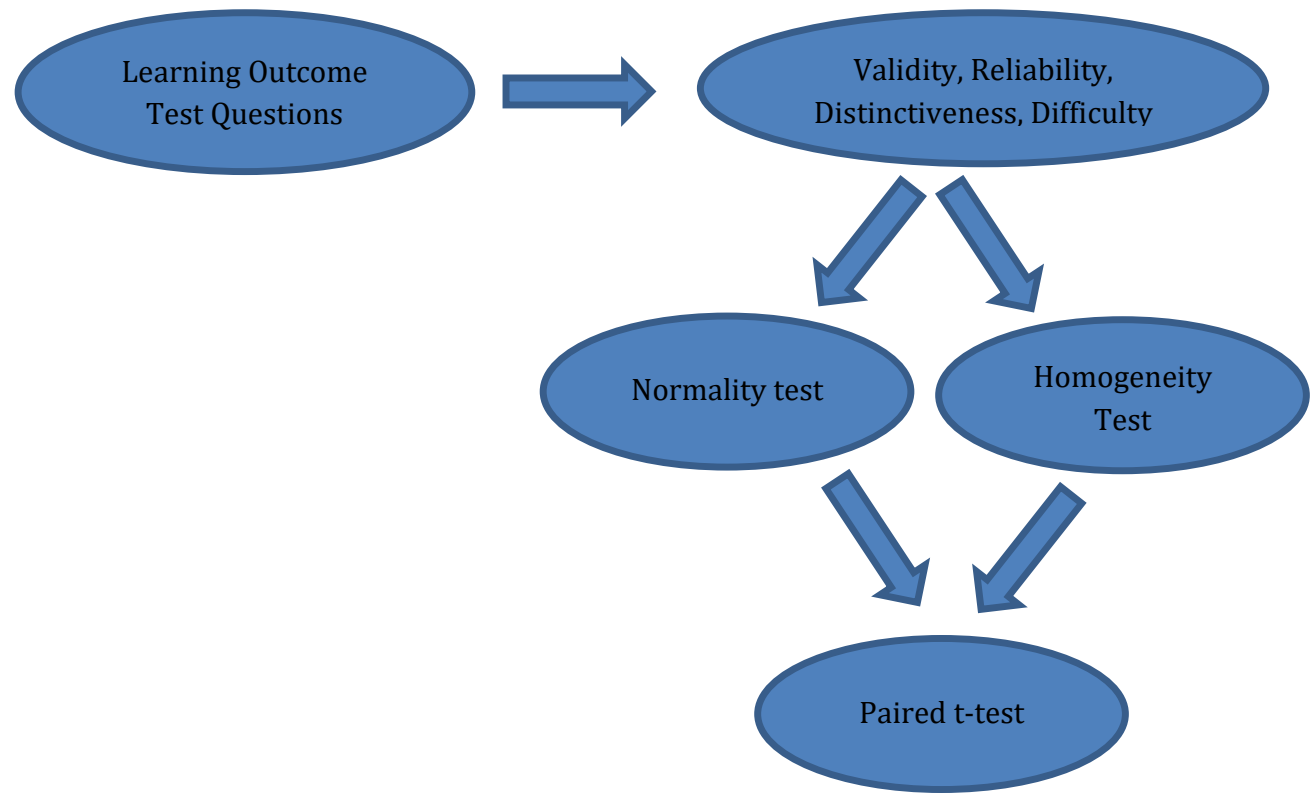

Figure 1. Research Method Flow Chart

\section{RESULTS AND DISCUSSION}

The results of this research focus on two aspects, namely online learning using the Whatsapp Group before using the learning video intervention and the whatsapp group after using the learning video intervention. Online learning was carried out in the $8^{\text {th }}$ grade of SMP Negeri 2 Bandar Lampung on the statistics material with the activity of giving a description test of 5 questions before a learning video intervention (pretest) was distributed through the WhatsApp group. It can be seen in table 1 below:

Table 1. Online Learning Outcome Data Using Whatsapp Group Before the Learning Video Intervention

\begin{tabular}{lr}
\hline \multicolumn{2}{c}{ Study Results Before Intervention } \\
\hline Valid N & 31 \\
Minimum & 10 \\
Maximum & 67 \\
Mean & 45.29 \\
Std.Deviation & 16.01 \\
\hline
\end{tabular}

The value obtained is the result of the five answers to the description test questions in which each question number has different points. The value obtained from the pretest before being given the learning video intervention treatment, namely the lowest value is 10 and the highest value is 67 with the average value obtained is 45.29 and the standard deviation is 16.01. It shows that the results of online learning using Whatsapp Groups before being given the learning video intervention treatment needs more attention so that learning outcomes increase by providing learning video interventions in online learning using Whatsapp Groups which are carried out during the current COVID-19 pandemic.

Online learning using whatsapp groups after being given the learning video intervention treatment on $8^{\text {th }}$ grade students of SMP Negeri 2 Bandar Lampung on statistics material is carried out by giving a description test of 5 questions after a learning video intervention (posttest) which is distributed via whatsapp group can be seen in table 2 below. 
Table 2. Online Learning Outcome Data Using Whatsapp Group After the Learning Video Intervention

\begin{tabular}{lr}
\hline \multicolumn{2}{c}{ Study Results After Intervention } \\
\hline Valid N & 31 \\
Minimum & 50 \\
Maximum & 85 \\
Mean & 68.35 \\
Std.Deviation & 10.75 \\
\hline
\end{tabular}

The $8^{\text {th }}$ grade students' knowledge of statistics material after being given learning video intervention treatment that were shared via whatsapp groups. The results were obtained from the posttest after being given the learning video intervention treatment, the minimum score obtained was 50, the maximum score obtained was 85 , the average score obtained was 68.35 , and the standard deviation obtained was 10.75. Based on these data, the average results of online learning using whatsapp groups with the learning video intervention treatment were successful and able to improve student learning outcomes. Comparison of online learning outcomes using whatsapp groups before and after being given the learning video intervention treatment can be seen in Figure 2:

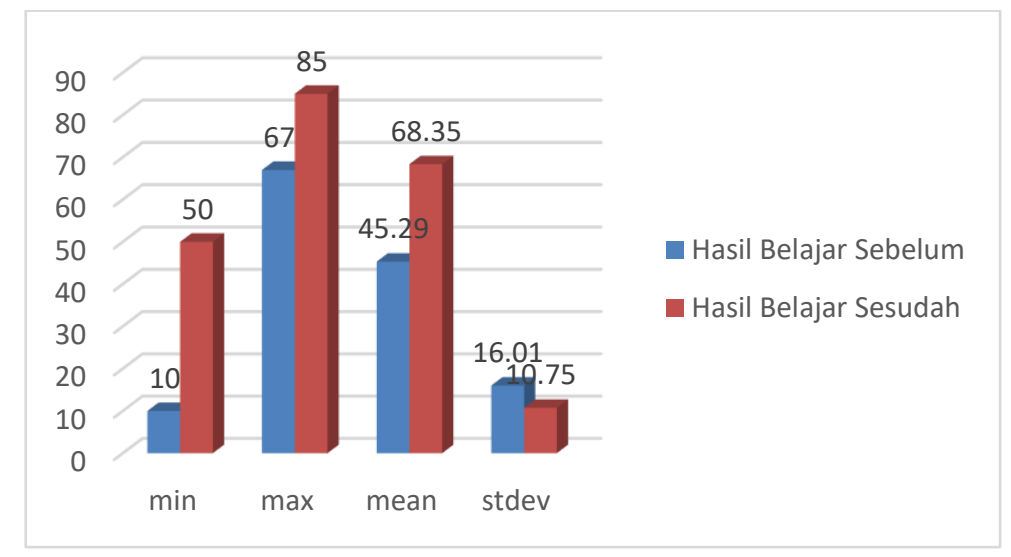

Figure 2. Learning Outcome Data Before and After Learning Video Intervention

Based on Figure 2, it is known that the minimum, maximum, and average learning outcomes of students with online learning using WhatsApp groups after being given the learning video intervention treatment are better than the learning outcomes of students with online learning using WhatsApp groups before being given the learning video intervention treatment. The standard deviation value in the pre-treatment group have a much greater value than the standard deviation in the post-treatment group. This is because the size of the data spread around the average in the pre-treatment data is greater than the post-treatment data.

Furthermore, the data processing of the Kolmogorov-Smirnov normality test was carried out using SPSS 20 in the data group before and after the learning video intervention treatment. The results of the data processing can be seen in Table 3 below:

Table 3. The Results of Kolmogorov-Smirnov Normality Test

\begin{tabular}{|c|c|c|c|}
\hline Treatment & $\begin{array}{c}\text { Significance Value of } \\
\text { K-S Test Results }\end{array}$ & $\begin{array}{c}\text { Significance Value } \\
\text { (p) }\end{array}$ & Conclusion \\
\hline Before & 0.2 & \multirow{2}{*}{0.05} & $\begin{array}{c}\text { Because } 0.2>0.05 \text {, the data is } \\
\text { normally distributed. }\end{array}$ \\
\hline After & 0.2 & & $\begin{array}{c}\text { Because } 0.2>0.05, \text { the data is } \\
\text { normally distributed. }\end{array}$ \\
\hline
\end{tabular}


Based on Table 3 above, the data can be proven to be normally distributed. Next, a paired ttest was conducted to prove that there was a difference in the average learning outcomes between online learning using WhatsApp groups without learning video intervention treatment and online learning outcomes using WhatsApp groups with learning video intervention treatment. The following table shows the results of paired t-test using SPSS 20:

Table 4. Paired t-Test Results

\begin{tabular}{cccc}
\hline & T & Df & Sig. (2-tailed) \\
\hline Pair 1 before-after & -7.736 & 30 & 0.00 \\
\hline
\end{tabular}

The results of the paired t-test in table 4 show that the acquisition of Sig. (2-tailed) is 0.00 , this means the value of Sig. (2-tailed) $0.00<0.05$, then $\mathrm{Ho}$ is rejected and $\mathrm{Ha}$ is accepted. This shows that there is a difference in the average learning outcomes between online learning using whatsapp groups without learning video intervention treatment and online learning outcomes using WhatsApp groups with learning video intervention treatment. In addition, it can be shown that the $t_{\text {calculate }}=-7.736$. The t-calculate value is negative because the average value of learning outcomes in online learning using WhatsApp groups without the learning video intervention treatment is lower than the average value of online learning outcomes using WhatsApp groups with the learning video intervention treatment. However, a negative t-calculate value can be positive, namely t-calculate $=7.736$ and with the value of $\alpha=5 \%$, the value of $t_{\text {table }}=t_{0.025 ; 30}=2.042$ because $7.736>2.042$, it means that $t_{\text {calculate }}>t_{\text {table }}$, so Ho is rejected and Ha is accepted, which means that there is a difference in average learning outcomes between online learning using WhatsApp groups without the learning video intervention treatment and online learning using WhatsApp groups with the learning video intervention treatment. The difference in the average learning outcomes can also be shown from the results of descriptive statistics with the acquisition of the average score of online learning outcomes using WhatsApp groups without the learning video intervention treatment on statistics material is 45.29, while the acquisition of the average score of online learning outcomes using WhatsApp group with the learning video intervention treatment on statistics material is 68.35. This means that online learning using WhatsApp groups with the learning video intervention treatment on statistics material is better in improving the mathematics learning outcomes for 8th grade students of SMP Negeri 2 Bandar Lampung during the COVID-19 Pandemic.

The results of this research complement several previous studies, (Saragih \& Ansi, 2020) found that there was an effectiveness of learning using WhatsApp groups during the COVID19 pandemic. Student motivation and learning outcomes after being treated using WhatsApp groups are higher than student learning outcomes before being treated using WhatsApp groups (Indaryani and Suliworo 2018; Nugraha et al. 2020; Yensy 2020). In addition, the results of the research from (Wahyuni, 2018) stated that the results of her research show that WhatsApp has features that support it to become a support media in the teaching and learning process. WhatsApp also helps facilitate the work of teachers. Other discoveries suggest that WhatsApp groups with the Group Discussion By Whatsapp type II learning model are effective in increasing student learning independence because students are very familiar in using WhatsApp groups, and the learning model applied to online learning through WhatsApp group media encourages every student to be active in participate/discuss (Susilowati, 2020). 
The application of WhatsApp groups combined with learning videos is one of the educators' efforts to overcome today's online learning.

\section{CONCLUSIONS}

Based on the data analysis and the discussion, it can be concluded that online learning using WhatsApp group media with the learning video intervention treatment provides better learning outcomes than using only WhatsApp group media. The results of this research are one of the alternatives offered in the implementation of online learning during the COVID-19 pandemic.

Based on the results of this research, suggestions that can be given are that the implementation of online learning during the pandemic using the WhatsApp application media and collaborating with the use of video as a learning media can be carried out and developed further. This is an alternative solution to problems that arise during the implementation of online learning. For further researchers, they can create a more interactive learning video for students.

\section{AUTHOR CONTRIBUTIONS STATEMENT}

TYH is the principal designer and researcher in this article. Data collection and instrument design assisted by RF.

\section{REFERENCES}

Agustin, L. L. T. 2020. Dampak pembelajaran daring dengan whatssapp group pada prilaku kreatif siswa (Studi kasus pembelajaran di kelas IV SD Terangmas Undaan Kudus).

Arizona, K., Abidin, Z., \& Rumansyah, R. (2020). Pembelajaran online berbasis proyek salah satu solusi kegiatan belajar mengajar di tengah pandemi COVID-19. Jurnal Ilmiah Profesi Pendidikan, 5(1), 64-70.

Bhagaskara, A. E., Afifah, E. N., \& Putra, E. M. (2021). Pembelajaran dalam jaringan (Daring) berbasis whatsapp di SD Yapita. ZAHRA: Research and Tought Elementary School of Islam Journal, 2(1), 13-23.

Busyaeri, A., Udin, T., \& Zaenudin, A. (2016). Pengaruh penggunaan video pembelajaran terhadap peningkatan hasil belajar mapel IPA di MIN Kroya Cirebon. Al Ibtida: Jurnal Pendidikan Guru MI, 3(1), 116-137.

Cahyani, A., Listiana, I. D., \& Larasati, S. P. D. (2020). Motivasi belajar siswa SMA pada pembelajaran daring di masa pandemi COVID-19. IQ (Ilmu Al-qur'an): Jurnal Pendidikan Islam, 3(01), 123-140.

Hartadi, D. R., Dewantoro, D. A., \& Junaidi, A. R. (2020). Kesiapan sekolah dalam melaksanakan pendidikan inklusif untuk anak berkebutuhan khusus di sekolah dasar. Jurnal Ortopedagogia, 5(2), 90-95.

Indaryani, E., \& Suliworo, D. (2018). Dampak pemanfaatan whatsapp dalam meningkatkan motivasi belajar siswa pada pelajaran fisika. In Quantum: Seminar Nasional Fisika, dan Pendidikan Fisika (pp. 25-31).

Iskandar, R. (2020). Penggunaan grup whatsapp sebagai media pembelajaran terhadap peserta didik Dta At-Tawakal kota Bandung. Comm-Edu (Community Education Journal), 3(2), 97-101. 
Iwantara, I. W., Sadia, I. W., \& Suma, K. (2014). Pengaruh penggunaan media video youtube dalam pembelajaran IPA terhadap motivasi belajar dan pemahaman konsep siswa. Jurnal Pendidikan Dan Pembelajaran IPA Indonesia, 4(1), 1-13.

Jumiatmoko, M. (2016). Whatsapp messenger dalam tinjauan manfaat dan adab. Wahana Akademika: Jurnal Studi Islam dan Sosial, 3(1), 51-66.

Khairani, M., Sutisna, S., \& Suyanto, S. (2019). Studi meta-analisis pengaruh video pembelajaran terhadap hasil belajar peserta didik. Jurnal Biolokus: Jurnal Penelitian Pendidikan Biologi dan Biologi, 2(1), 158-166.

Nugraha, S. A., Sudiatmi, T., \& Suswandari, M. (2020). Studi pengaruh daring learning terhadap hasil belajar matematika kelas IV. Jurnal Inovasi Penelitian, 1(3), 265-276.

Nuritha, C., \& Tsurayya, A. (2021). Pengembangan video pembelajaran berbantuan geogebra untuk meningkatkan kemandirian belajar siswa. Jurnal Cendekia: Jurnal Pendidikan Matematika, 5(1), 48-64.

Pamungkas, A. S., Ihsanudin, I., Novaliyosi, N., \& Yandari, I. A. V. (2018). Video pembelajaran berbasis sparkol videoscribe: Inovasi pada perkuliahan sejarah matematika. Prima: Jurnal Pendidikan Matematika, 2(2), 127-135.

Pane, A., \& Dasopang, M. D. (2017). Belajar dan pembelajaran. Fitrah: Jurnal Kajian IlmuIlmu Keislaman, 3(2), 333-352.

Pohan, A. E. (2020). Konsep pembelajaran daring berbasis pendekatan ilmiah. Penerbit CV. Sarnu Untung.

Pustikayasa, I. M. (2019). Grup whatsapp sebagai media pembelajaran. Widya Genitri: Jurnal Ilmiah Pendidikan, Agama Dan Kebudayaan Hindu, 10(2), 53-62.

Rachmat, A., \& Krisnadi, I. (2020). Analisis efektifitas pembelajaran Daring (online) untuk siswa SMK negeri 8 kota Tangerang pada saat pandemi COVID-19. Jurnal Pendidikan, $1(1), 1-7$.

Saragih, E. M., \& Ansi, R. Y. (2020, October). Efektivitas penggunaan whatsapp group selama pandemi COVID-19 bagi pelaku pendidik. In Seminar Nasional Multi Disiplin Ilmu Universitas Asahan.

Sari, D. P., \& Rusmin, A. R. (2018). Pengaruh iklim kelas terhadap motivasi belajar peserta didik di SMAN3 Tanjung Raja. Jurnal Profit: Kajian Pendidikan Ekonomi Dan Ilmu Ekonomi, 5(1), 80-88.

Subur, J. M., \& Rista, N. (2020). Pengaruh pembelajaran online pada masa pandemi COVID19 terhadap hasil belajar mata pelajaran ilmu pengetahuan sosial siswa kelas VIII Di SMP Walisongo Bekasi. JUSIE (Jurnal Sosial Dan Ilmu Ekonomi), 5(02), 156-161.

Susilowati, E. (2020). Bagaimana pembelajaran daring di tengah wabah COVID 19 melalui grup whatsapp?. Jurnal Pendidikan Matematika Raflesia, 5(3), 1-25.

Syarifudin, A. S. (2020). Impelementasi pembelajaran daring untuk meningkatkan mutu pendidikan sebagai dampak diterapkannya social distancing. Jurnal Pendidikan Bahasa Dan Sastra Indonesia Metalingua, 5(1), 31-34.

Wahyuni, N. (2018). Peran penggunaan grup whatsapp dalam proses belajar mengajar di SMK Negeri 2 Banjarmasin. Jurnal Mutakallimin: Jurnal Ilmu Komunikasi, 1(2), 19-26. 
Yensy, N. A. (2020). Efektifitas pembelajaran statistika matematika melalui media whatsapp group ditinjau dari hasil belajar mahasiswa (masa pandemik COVID-19). Jurnal Pendidikan Matematika Raflesia, 5(2), 65-74.

Yunita, D., \& Wijayanti, A. (2017). Pengaruh media video pembelajaran terhadap hasil belajar IPA ditinjau dari keaktifan siswa. Sosiohumaniora: Jurnal Ilmiah Ilmu Sosial Dan Humaniora, 3(2). 